\title{
Associated Petroleum Gas Flaring: The Problem and Possible Solution
}

\author{
A. Vorobev ${ }^{1,2(\bowtie)}$ and E. Shchesnyak ${ }^{2}$ \\ 1 Atyrau University of Oil and Gas, Atyrau, Kazakhstan \\ fogel_al@mail.ru \\ 2 Peoples' Friendship University of Russia (RUDN University), \\ Moscow, Russia
}

\begin{abstract}
The article analyzes the current state and prospects for utilization of a hydrocarbon component dissolved in oil and released during its extraction and preparation - associated petroleum gas (APG). The authors studied the properties, characteristics and component composition of APG.

The analysis of the APG use at the international and regional levels is carried out. The main causes of flaring were discussed and the shortage of production capacities for APG processing in the Russian Federation was noted as one of the main factors in the high level of APG flaring in the country.

The paper notes possible ways of utilization of associated petroleum gas, which depend on oil production conditions, such as field characteristics, oil/gas ratio (gas-oil factor), and market opportunities for recovered gas. An overview of all APG utilization methods are presented, which focuses on unit costs, economic benefits and environmental impact reduction. The authors analyzed the innovative experience of effective APG use in the USA and Canada. Special attention is paid to the need to solve the problem of the effective use of APG in the Russian Federation, especially the reduction of its burning in flare plants.
\end{abstract}

Keywords: Associated petroleum gas - Associated petroleum gas utilization · APG flaring $\cdot$ Environmental pollution

\section{Introduction}

Associated petroleum gas (APG) is a kind of natural gas that is in oil deposits, either dissolved in oil or as a free "gas cap" over oil into the deposits. Regardless of the source, as soon as it separates from crude oil, it usually exists in mixtures of other hydrocarbons such as ethane, propane, butane and pentane; in addition, APG contains water vapor, hydrogen sulfide $\left(\mathrm{H}_{2} \mathrm{~S}\right)$ and carbon dioxide $\left(\mathrm{CO}_{2}\right)$, nitrogen $\left(\mathrm{N}_{2}\right)$ and other mixtures. Associated petroleum gas containing such impurities so it can not be transported and used without purification, as it is extracted in the process of oil production (Kartamysheva et al. 2017).

The volume and composition of APG depends on the area of production and on the specific properties of the field. In the process of extraction and separation of one ton of oil, it is possible to obtain from 25 to $800 \mathrm{~m}^{3}$ of associated gas. Some of this gas is used or stored, because governments and oil companies have made significant investments 
for its extraction. However, individual companies burn APG because of technical, regulatory or economic constraints. As a result, thousands of flare stacks from more than 17,000 oil production facilities around the world burn about 140 billion cubic meters of natural gas per year, resulting in more than 350 million tons of $\mathrm{CO}_{2}$ and a large variety of pollutants, including very dangerous.

The overall increase in global flaring compared to previous years is largely due to negative developments in only a few countries: Iran, Russia and Iraq. Satellite data show an increase in flaring in Iran by more than 4 billion $\mathrm{m}^{3}$, in Russia by almost 3 billion $\mathrm{m}^{3}$ and more than 1 billion $\mathrm{m}^{3}$ in Iraq. Flaring in Russia is close to the global average compared to oil production; in the other two countries, flaring intensity is higher. This is the expenditure of a valuable energy resource that can be used to promote the sustainable development of producing countries. Thus, 149 billion $\mathrm{m}^{3}$ of associated petroleum gas, burned in 2018, could turn into 750 billion $\mathrm{kWh}$ of electricity, which exceeds its total annual consumption by all countries of the African continent.

According to official data, the volume of extracted APG in Russia increased by more than $7 \%$ - to 65 billion $\mathrm{m}^{3}$ in 2010 and over 70 billion $\mathrm{m}^{3}$ in 2018 . The immediate impact on the increase in the volume of recoverable APG was made by the growth of oil production in new areas, including the East Siberian fields.

\section{Methods and Approaches}

For a long time, oil companies simply burned this unwanted by-product. Its flaring requires a significant portion of the security system.

The term "gas flaring" indicates a gas combustion (without energy recovery) in an open flame, which is continuously lit on top of the flare stacks in the field of oil production (Knizhnikov et al. 2017).

Flaring occurs for three main reasons:

- emergencies: limited incineration for reasons of safety for short periods of time can always be necessary even after connecting the gas gathering pipeline;

- deficiency of gas utilization capacity - isolated well flaring: if the well starts to produce oil and gas without connecting to gas gathering pipeline or other gas utilization technology, the gas can be shut off;

- lack of gas utilization capacity - well burning through the pipeline: if the well is connected to gas gathering pipeline, but these systems can not process all gas from the well (due to lack of power or compression), some or all of the associated gas from the well can be flared.

Billions of cubic meters of natural gas are burned at oil production sites around the world. Gas combustion is a costly energy resource that can be used to support economic growth and progress (Vorob'ev et al. 2017).

Since 2012, the US National Oceanic and Atmospheric Administration and the Global Gas Flaring Reduction Partnership have begun to apply a method for estimating the volume of APG flared. This method consists in the use of satellite observational data in the visible and near infrared ranges. 
The conclusion drawn from the research results is that the volume of flared APG in the world increased to 147 billion $\mathrm{m}^{3}$ in 2015 , compared with 145 billion $\mathrm{m}^{3}$ in 2014 and 141 billion $\mathrm{m}^{3}$ in 2013 . According to data for 2015, Russia led this "anti-rating", burning 24 billion $\mathrm{m}^{3}$ of APG, followed by Iraq (17.5 billion $\mathrm{m}^{3}$ ), Iran (16 billion $\mathrm{m}^{3}$ ) and the United States ( 8 billion $\mathrm{m}^{3}$ ). Russia is also a "leader" (in third place after the USA and Canada) with 1,814 flare stacks, which burn APG.

At present, there are other possible ways of utilization of associated gas, alternative to flaring. Among them it is necessary to single out the following:

- re-injection of APG into oil reservoirs to maintain pressure and increase oil recovery (as a method of increasing oil recovery), or for possible conservation of it as a resource and use in the future;

- the use of gas as an energy source for production site or at oil producing facilities in the vicinity;

- the most effective way of utilization of associated petroleum gas is its processing at gas processing plants to produce dry stripped gas ( $\mathrm{SOH})$, a wide fraction of light hydrocarbons (LH), liquefied natural gas (LNG) and stable gasoline (SG).

Below is an overview of all APG utilization methods, which focus on unit costs, economic benefits and environmental impacts.

\section{Results and Discussion}

The indicator of its useful use has remained stable since the 2000 s, within $73-79 \%$ of the total amount of extracted APG in the country. Only in 2014-2017, according to the public accounts of companies, it rose to $85-86 \%$. According to the statement of representatives of government organizations, the indicators of productive processing of APG amounted to $90 \%$ in 2018 .

The amendments to the law "On environmental protection” (№ 219) adopted in July 2014 caused such as significant reduction in the share of associated gas combustion, according to these amendments, the company is obliged to establish its technological standards at the level of application of the best available technologies. The total investment in increasing the useful use of APG was estimated at 200 billion rubles. According to the Ministry of energy of the Russian Federation, it is expected that the target of $95 \%$ of the associated gas will be used by the end of 2020 (Vorobyev et al. 2018).

Foreign experience of utilization of APG shows that flaring of gas in torches has decreased slightly over the past two years, and oil production has also declined. In particular, Nigeria reduced volume APG combustion to 8 billion $\mathrm{m}^{3}$ of nearly $18 \%$ compared with 2013 year. The volume of associated gas flaring in the USA decreased from 11 billion $\mathrm{m}^{3}$ in 2016 to less than 9 billion $\mathrm{m}^{3}$ in 2018 due to the use of a number of innovative low-volume technologies.

One of the innovative technologies for the production of liquefied natural gas with small volumes of associated petroleum gas is LNG Production (Production Natural Gas Liquids, LH-Pro). The "LH Pro" process combines dehydration, compression, cooling and conditioning, eliminating the need for expensive glycol and refrigeration systems. 
Hydrate formation is excluded due to the thermal integration system. The technology was developed by ASPEN and is used in the US and Canada.

\section{Conclusions}

Thus, the most rational ways of utilization of associated petroleum gas in Russia, depending on the volumes of its extraction are:

- at small volumes - covering own energy needs;

- with increased volumes - electricity generation and primary processing of APG to produce lean dry gas (LDG) as fuel for the boiler room and light hydrocarbons (LH) for disposal to the oil collector;

- at resources from 50 to 150 million $\mathrm{m}^{3} /$ year - processing with obtaining LDG, as well as LH and electricity;

- with the amount of APG in excess of 150 million $\mathrm{m}^{3} /$ year, processing of LDG, and NGL is recommended.

\section{References}

Kartamysheva YeS, Ivanchenko DS (2017) Associated petroleum gas and the problem of its utilization. Molodoy uchenyy. № 25, pp 120-124

Knizhnikov AYU, Il'in AM (2017) Problems and prospects of associated petroleum gas use in Russia. 2017 WWF Rossii, Moscow, p 34

Vorob'ev A, Chekushina T, Vorob'ev K (2017) Russian national technological initiative in the sphere of mineral resource usage. Rudarsko Geolosko Naftni Zbornik 2:1-8

Vorobyev AE, Zhang L (2018) Analysis of production and consumption of associated petroleum gas in China. Bulletin of Atyrau Institute of oil and gas № 2(46), pp 137-142

Open Access This chapter is licensed under the terms of the Creative Commons Attribution 4.0 International License (http://creativecommons.org/licenses/by/4.0/), which permits use, sharing, adaptation, distribution and reproduction in any medium or format, as long as you give appropriate credit to the original author(s) and the source, provide a link to the Creative Commons license and indicate if changes were made.

The images or other third party material in this chapter are included in the chapter's Creative Commons license, unless indicated otherwise in a credit line to the material. If material is not included in the chapter's Creative Commons license and your intended use is not permitted by statutory regulation or exceeds the permitted use, you will need to obtain permission directly from the copyright holder.

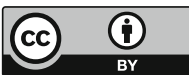

